\title{
IMPROVING FRUIT CRACKING RESISTANCE OF WONDERFUL POMEGRANATES
}

\author{
Mai H. Ismail ${ }^{1}$; N. Abd-Alhamid ${ }^{1}$; Eman S. Sewrus ${ }^{2}$ and Samah Nasr ${ }^{3}$ \\ 1- Horticulture Dept., Fac. of Agric., Ain Shams Univ., Cairo, Egypt \\ 2- Horticulture Research Institute, Agricultural Research Center, Giza, Egypt \\ 3- Higher Institute for Agriculture Co-Operation, Cairo, Egypt
}

Keywords: Pomegranate (Punica granatum L. wonderful); Foliar spray; Potassium silicate, Kaolin, Zinc oxidase; Boron; Fruit cracking, Fruit quality pomegranates

\section{ABSTRACT}

The present investigation was carried out in two successive seasons of 2015 and 2016 on Wonderful" Pomegranates trees grown in sandy soil under drip irrigation system in a private orchard located at Giza governorate, Egypt. Trees were sprayed two times (at fruits size 8-10 mm \& Respraying at one month later) with Potassium silicate at $(2500 \& 5000 \mathrm{ppm})$, Boron at $(5 \& 10 \%)$, Kaolin (1 \&2\%), Zinc oxidase (1000 \& 2000 ppm) with wrapping as a commercial treatments . Spraying started at July in the two seasons to improve fruit cracking resistance "Wonderful" pomegranates and study their effects upon yield components, physical and chemical fruit properties.

Results indicated that the "Wonderful" pomegranates cultivar had the highest values of fruit weight and the minimum cracking values were obtained by spraying Boron at $(5 \%)$ and potassium silicate at (5000 ppm) in both seasons and this treatments gave the maximum values with total yield/tree, /feddan and Marketable yield/tree, /feddan .Meanwhile ,number of arils per fruit ,total soluble solids, total sugar ,total acidity, (arils)/fruit weight was not affected but when trees treated with wrapping, without wrapping and zinc oxidase at (1000 ppm) sprays gave the minimum mentioned above characteristics. However, fruit weight, arils weight, ascorbic acid, anthocyanin and tannins \%were increased as influenced by foliar spraying with all treatments in both studied seasons.
Therefore, boron at $5 \%$ and Potassium silicate at $5000 \mathrm{ppm}$ treatments could be recommended for improving Wonderfull pomegranate cvs performance in cracking resistance alternative treatments to fruit wrapping under similar conditions of this study.

\section{INTRODUCTION}

Pomegranate (Punica granatum $\mathrm{L}$ ) belongs to family Punicaceae, considered one of the oldest cultivated trees in the history of the world cultivated about 5000 years ago. although it is one of the oldest known edible fruits and is capable of growing in different agro-climatic conditions ranging from the tropical to subtropical . It is highly suitable for growing under arid and semiarid regions due to its versatile adaptability, hardy nature, low cost maintenance and high returns. (Al-Maiman and Ahmad, 2002 \& Sarkhosh et al 2006 \& Hamouda et al 2015)

Fruit cracking is one of the physiological on pomegranate fruit is very scanty. Fruit cracking is a serious problem in pomegranate which hinders its cultivation to a large extent. Cracking varies from 10 to $70 \%$ depending upon the prevailing environmental conditions. Various factors are responsible for fruit cracking which include fluctuation in soil moisture regimes, climate, tree nutrition and cultivars (Kumar et al 2010). It may also occur to micronutrient deviancy in young fruit while in mature fruit might be moisture imba; ance ((Hegazi et al 2014) or due to extreme variations in day and night temperature ( Abd- El-Rahman, 2010) Cracked fruits are susceptible to storage disease and have a shorter storage as well as shelf-life (Hegazi et al 2014) . 
Fruit bagging is one of the most effective techniques to produce high quality, pollution-free fruits and got more attentions to the fruit producers during the recent decades were obvious. The quality of fruit bagging has been getting better and better. The effect of bagging on appearance quality (brightness, color, size and weight of single fruit), the quality of fruit contents such as total soluble solids, titrable acids, vitamin $\mathrm{C}$, become more apparent procedure Also, the influence of bagging on fruit maturity period, storage property, protection of plant disease, insect pets ,and sunburn (Jing, 2009). However Bambal et al (1991) found that foliar application of some micronutrients such as $\mathrm{Si}, \mathrm{B}, \mathrm{ZnO}$, and $\mathrm{K}$ increased fruit yield, whereas $\mathrm{B}$ reduced the percentage of cracked fruits.

Although, the effect of foliar applied chemicals on yield and fruit quality have been studied by many workers the information of such effect on pomegranate fruit is very scanty. (Hasani et al 2012). Kaolin has recently been utilized in the development of hydrophilic particle film technology. This technology uses chemically inter, non - toxic mineral particles coat to plant surfaces(Glenn et al 1999). Kaolin application showed significantly positive effect on protection of fruit against sunburn on Fuji and Honeycrips apple cultivars (Schupp et al 2002) These positive results on Kaolin application was also confirmed with studies of Melgarejo, et al (2004); Abd El-Rhman, (2010) and Samra \& Shalan (2013) on pomegranate and Glenn et al (1999) on apple cultivars.

Kaolin also is an important material used in this concern, it is considered as an effective natural antitranspirant and was reported to mitigate the negative effects of water deficiency and environmental stresses, such as heat stress and sunburn damage as well as suppress diseases and protect crops from insect pests (Kahn and Damicone, 2008). Spraying tomato plants with 5\% of kaolin suspension improved water status and yield under water stress conditions Creamer et al (2005) illustrated that applications of kaolin at hot temperatures might help hot Chile pepper plants from being subjected to severe water stress. the main role of potassium is the activation of many enzyme systems involved in the structure of organic substances and promotes photosynthesis and transport of the assimilates of the carbohydrates to the storage organs.

In addition, $\mathrm{K}$ is involved in several basic physiological functions. It resulted also in improving the fruit quality parameters, i.e., TSS \%, Total sugars and coloration (Wahdan et al 2011). These effects might be dedicated to the potassium role in increasing tolerance to stresses and improving the formation and accumulation rates of sugars (Saleh and Abd El-Monem, 2003 and Baiea et al 20115).

Silicon (Si) is the second abundant element in the crust of earth and in plants in which its content in plant is \%0.1 to \%10 of dry weight. (Epstein 1999 and Hassan et al 2013). Although silicon is not considered an essential element for plant nutrition, many authors report on beneficial effects when its supply to various cultivated plants is enhanced. In most cases, the favorable effects of $\mathrm{Si}$ on crop plants seem to originate from reinforcement of the cell walls due to deposition of $\mathrm{Si}$ in form of amorphous silica $\left(\mathrm{SiO}_{2} \cdot \mathrm{nH}_{2} \mathrm{O}\right)$ and opal phytoliths ( Epstein 1999) \& Stamatakis et al 2003). Moreover, the mechanical strength provided by $\mathrm{Si}$ to the plant tissues increases their resistance to several bacterial, fungi and insect diseases (Menzies, et al 1991\& Epstein 1999). Si has been reported to generally improve plant growth, a feature linked to the ability of $\mathrm{Si}$ to balance nutrient uptake or the general enhancement of nutrient transport and distribution by Si (Gong, et al 2005, Bertling et al 2009). Apart from the physical action of $\mathrm{Si}$ deposits in cells, $\mathrm{Si}$ can also associate with cell wall proteins, where it might exert an active biochemical function, possibly through production of defence compounds (Chérif et al 1994). which could reduce pathogen attacks, Therefore, Si applications could improve the postharvest fruit quality of avocado, not only through reducing pest and disease incidences but also by altering certain fruit parameters .Recently, silicon dips have an ability to reduce chilling injury symptoms in lemons; however low concentration should be used (Bertling et al 2009 \& Mditshwa et al 2013). The most commonly used from of $\mathrm{Si}$ in agricultural commodities is currently potassium silicate $\left(\mathrm{K}_{2} \mathrm{SiO}_{3}\right)$, although other products, such as calcium $\left(\mathrm{CaSiO}_{3}\right)$ and sodium silicate $\left(\mathrm{Na}_{2} \mathrm{SiO}_{3}\right)$ as well as NonToxsilica are available. However, as these products are either less soluble than $\mathrm{KSil}$ or, like $\mathrm{Na}$, might affect fruit quality negatively (Bertling et al 2009). Zinc is an essential component of some enzymes such as dehydrogenase, proteinase and peptidases. In this regard, zinc can affect electron transfer reactions such as the Krebs cycle and energy production of the plant. Zinc is also involved in other reactions such as protein construction and analysis (Bose et al 1988). Zinc is a prerequisite for making tryptophan and trryptophan is the raw material for making auxin and auxin plays an important role 
in increasing the leaf area and tree canopy. Foliar application of $0.25 \%$ of zinc significantly increased the yield vitamin C, TSS , total acid and juice \% of pomegranate (Balakrishnan et al 1996) Zn. Recently, bio fertilization of pomegranate, has improved its yield and decreased cracking of fruit ( Aseri et al 2008). Therefore, they may be new alternatives to soil and foliar application of fertilizers for pomegranate orchards. (Khorsandi, et al 2009).

Boron and $\mathrm{Zn}$ deficiencies are more probable early in the season because the translocation of elements from the root to the aboveground portion may not be adequate before leaf expansion. Zinc and $B$ have a critical effect on flowering and fruit set and for this reason spring foliar application of these elements are frequently recommended in fruit orchards (Neilsen, et al 2004)

Zinc and boron have promising effect on plant metabolism. They are responsible for producing the natural hormones IAA, activating some enzymes biosynthesis of chlorophylls, enhancing germination of pollens and regulating water uptake by plants (Nijjar, 1985).. Foliar application of nutrients, especially boron and zinc was essential for producing healthy fruit trees as well as producing productive trees. In addition, they are responsible for improving physical and chemical parameters of fruits (Banik, et al 1997\& Srihari \& Rao, 1998 and Bahadur et al 1998 ).

The positive effect of foliar application of zinc in increasing the productivity. (Singh \& Maurya, 2004 and Ranjit et al 2008) and improving the fruit quality in terms of TSS and total sugars (Rashmi et al 2007). Boron has effect on many functions of the plant such as hormone movement, activate salt absorption, flowering and fruiting process and pollen germination specially its influences on the directionality of pollen tube growth, it seems to play an important role in achieving satisfactory fruit set (Baldi, et al 2004 \& Khayyat, et al 2007 and Abdel-Fattah et al 2008).

The objectives of this study are to evaluate the use of spraying some substance such as Zinc oxidase, Kaolin, Potassium silicate, Boron , and fruit wrapping (bagging) on yield, physical and chemical fruit characteristics as well improving fruit cracking resistance of "Wonderful" pomegranates.

\section{3- MATERIALS AND METHODS}

This study was carried out during two successive seasons, (2015and 2016) in a private orchard located at Giza governorate, Egypt. Thirty uniform healthy pomegranate trees of Wonderful cv. Five years old were chosen for this study. Trees grown on sandy soil, drip irrigation system was used and planted. at $3.5 \times 3.0$. A regular pest management program was maintained. In both seasons, the selected trees were divided into different ten treatments included the control treatments. The treatments were arranged as follows:

1. Boric acid at $5 \mathrm{ppm}$

2. Boric acid at $10 \mathrm{ppm}$

3. Zinc oxidase $(\mathrm{ZnO})$ at $1000 \mathrm{ppm}$

4. Zinc oxidase $(\mathrm{ZnO})$ at $2000 \mathrm{ppm}$

5. Kaolin $\mathrm{AL}_{2} \mathrm{Sl}_{2} \mathrm{O}_{5}$ at $1 \%$

6. Kaolin $\mathrm{AL}_{2} \mathrm{Sl}_{2} \mathrm{O}_{5}$ at $2 \%$

7. Potassium silicate $\mathrm{K}_{2} \mathrm{Sio}_{3}$ at $2500 \mathrm{ppm}$

8. Potassium silicate $\mathrm{K}_{2} \mathrm{Sio}_{3}$ at $2500 \mathrm{ppm}$

9. Commercial (sprayed with water only and wrapped with paper as commercial treatment)

10. Control (sprayed with water only)

The experiment was designed as a completely randomized blocks design with three replicates and each replicate was replicates by one tree. All treatments were applied as spraying twice/year ( (after at fruits size $8-10 \mathrm{~mm}$ and re- spraying on the same trees at one month later ). Control fruits were wrapped with pepper as commercial treatment at mid July in both seasons.

\section{The following measurements were recorded}

1. Yield components: Fruits were harvested at mature stage in the two successive years at mid September. The number of fruit per tree was counted and then, the yield per tree was calculated either fruit number or $\mathrm{Kg} / \mathrm{tree}$.

- Fruit weight (g): A sample of ten fruits per replicate (tree) was weighed at mature stage.

- Fruit cracking percentage (\%)

The percentage of cracked fruits was calculated at mature stage as follows:

\section{Number of cracking fruits/tree \\ Cracking $(\%)$ = ------------- x100 \\ Total number of fruits/tree}

- Marketable fruits $\%=$ Total No. of fruits - Total No. of cracked fruits $\times 100$. 
Five normal fruits was taken from each tree in all treatments for physical and chemical determination as follows :

2. Fruit physical characteristics: fruit peel weight (g), fruit arils weight (g) and fruit peel thickness (cm) were measured. The fruit length and diameter (cm): were measured by a Digital Electronic caliper.

\section{Fruit chemical properties}

- Total soluble solid: (TSS) was measured by the refractive index expressed as ${ }^{\circ} \mathrm{Brix}$ with an Erma hand refractometer (reading at $20^{\circ} \mathrm{C}$ ) [Palou et al 2007].

- Titratable acidity: was determined as gm malic acid / 100 m juice (A.O.A.C, 2000)

- Total sugars (\%): was determined as gm / 100 $\mathrm{g}$ fresh weight according to (A.O.A.C, 2000).

- Ascorbic acid content (mg/100g F.wt): The Lascorbic acid content (V.C) was determined and expressed as $\mathrm{mg} / 100 \mathrm{~g}$ fresh weight following the methods by (A.O.A.C. 2000).

- Pigment anthocyanins content (\%): Total anthocyanins was extracted from one gram pulp fresh weight with $100 \mathrm{~mm} .0 .1 \%$ methanolic $\mathrm{HCL}$, the solution filtered and absorbency measured at $520 \mathrm{~nm}$ on Spekol 11 spectrophotometer [A.O.A.C. 2000].

- Total tannins (\%): Total tannins were determined by using Folin Denis colorimetric method (A.O.A.C. 2000) at $760 \mathrm{~nm}$ wave length. The concentration was calculated from a standard curve of pyrogallol as percentage.

\section{Statistical analysis}

Tannins content was determined in each sample by Swain and Hillis [1959].

The experiment was a completely randomized design (CRD) with factorial arrangement. Comparison between means was evaluated by Duncan's Multiple Range Test at 5\% level of significance. All storage treatments were done with three replications according to Sendecor and Cochran 1982

\section{RESULTS AND DISCUSSION}

\section{1- Yield components}

\section{- Total Yield / Tree $(\mathrm{Kg})$ \& Marketable and Cracking (\%)}

Results presented in Table (1) showed the Effect of spraying some substance to improve fruit cracking resistance "wonder full" pomegranates on Total yield/tree $(\mathrm{Kg})$, Cracking (\%), Marketable yield/ tree $(\mathrm{Kg})$ and No of fruit/tree, during 2015 and 2016 seasons.
As for the effect of treatments, it is evident that all concentrations of Zinc oxidase, Kaolin and Potassium silicate, as well as Boron treatment significantly increased the total yield/tree $(\mathrm{Kg})$ \& marketable and reduced Cracking (\%) than the control in the two seasons. The most effective treatments which were measured with the lowest crack and highest yield with $\mathrm{K}_{2} \mathrm{O}_{3} \mathrm{Si}$ at 5000 which gave (30.8 \& $30.2 \mathrm{Kg}$ Marketable yield/Fed and 9.1 \& 8.4 Cracking percentage) during 2015 and 2016 seasons, respectively. Cracking fruit in wonderful pomegranate were recorded by silicate treatment may be influencing cell well strength elasticity. Tree treated with $\mathrm{Br}$ at 5 and $10 \mathrm{PPm}$ with slight differences among them which gave (28.3 \& 27.7 $\mathrm{kg}$ and $11.3 \& 2.6 \%$ first season and $27.9 \& 26.9$ $\mathrm{kg}$ and $12.4 \& 14.4 \%$ in second season, followed by two concentration of kaolin which gave average values. Glenn \& Puterka (2007) presented that Kaolin increases carbon assimilation, which results in higher fruit yield and better coloration. Also, Palitha et al (2010) reported that Kaolin spraying significantly reduced damage of pomegranate fruit peel Ergun (2012) Samra et al 2013 mentioned that kaolin has emerged as the most important film resource for plants. This non-toxic film resource, has been used for reflecting radiation, especially UV wavelengths, reaching the surface of leaves and fruits. Whereas the tree treated with $\mathrm{ZnO}$ at $1000 \mathrm{PPm}$ considered the of less treatments where it gave the lowest amount of marketable yield/Fed $20.8 \& 20.4 \mathrm{Kg}$ and the highest percentage of cracking 18.6 \& 20.9 during 2015 and 2016 season .

Regarding control treatments (trees unsprayed) showed the worst treatments where the cracking rate gave nearly a quarter of total yield/tree (20.3 \& $23.3 \%$ with wrapping and $24.7 \& 25.5 \%$ with no bagging during both seasons

\section{- No of fruit/tree}

No significant differences were noticed No of fruit/tree with all treatment under study, while it ranged from 68.5 to 63.3 fruits in the frits season and 70.0 to 65.5 in the second season.

Reduced fruit cracking could be due the effect of auxins and enzymes which influenced hydrolytic activity and increased plasticity of cell walls (Taiz and Zeiger, 2006). Such physiological effect of these biostimulants may possibly result in preventing the cracking (Sekse et al 2005). Silicon was reported to alleviate water stress by its reduction effect on the diameter of stomatal pores (Efimova and Dokynchan, 1986) that in turn, reduces tran 
Table 1. Effect of spraying some substance to improve fruit cracking resistance "Wonderfull" pomegranates on Total Yield / Tree (Kg), Cracking (\%), Marketable yield/tree (Kg) and No of fruit/tree, during 2015 and 2016 seasons

\begin{tabular}{|c|c|c|c|c|c|c|c|c|}
\hline \multirow[b]{2}{*}{ Treatments } & \multicolumn{2}{|c|}{ Total Yield / Tree (Kg) } & \multicolumn{2}{|c|}{ Marketable yield/Fed (Kg) } & \multicolumn{2}{|c|}{ Cracking (\%) } & \multicolumn{2}{|c|}{ No of fruit/tree } \\
\hline & $\begin{array}{c}\text { Season } \\
2015\end{array}$ & $\begin{array}{c}\text { Season } \\
2016\end{array}$ & $\begin{array}{c}\text { Season } \\
2015\end{array}$ & $\begin{array}{c}\text { Season } \\
2016\end{array}$ & $\begin{array}{c}\text { Season } \\
2015\end{array}$ & $\begin{array}{c}\text { Season } \\
2016\end{array}$ & $\begin{array}{c}\text { Season } \\
2015\end{array}$ & $\begin{array}{c}\text { Season } \\
2016\end{array}$ \\
\hline $\mathrm{Br}$ at $5 \mathrm{PPm}$ & $31.8 \mathrm{AB}$ & $31.9 \mathrm{~A}$ & $8.3 \mathrm{~B}$ & $27.9 \mathrm{~B}$ & 11.3E & $12.4 \mathrm{E}$ & $66.3 \mathrm{~A}$ & $67.0 \mathrm{~A}$ \\
\hline $\mathrm{Br}$ at $10 \mathrm{PPm}$ & $31.7 \mathrm{AB}$ & $31.5 \mathrm{AB}$ & $27.7 \mathrm{BC}$ & $26.9 \mathrm{BC}$ & $12.6 \mathrm{E}$ & $14.4 \mathrm{D}$ & $66.5 \mathrm{~A}$ & $70.0 \mathrm{~A}$ \\
\hline ZnO at 1000 PPm & $25.5 \mathrm{D}$ & $25.8 \mathrm{DE}$ & $20.78 \mathrm{~F}$ & $20.4 \mathrm{FG}$ & 18.6BC & $20.9 B$ & $65.3 \mathrm{~A}$ & $65.0 \mathrm{~A}$ \\
\hline ZnO at 2000 PPm & $31.2 \mathrm{BC}$ & $26.8 \mathrm{D}$ & 25.73DE & $21.71 \mathrm{EF}$ & $17.6 \mathrm{C}$ & 19.3BC & $68.5 \mathrm{~A}$ & $65.5 \mathrm{~A}$ \\
\hline AL2 SI2 O5 at $1 \%$ & $29.2 \mathrm{C}$ & $31.1 \mathrm{AB}$ & $24.4 \mathrm{E}$ & $25.3 \mathrm{CD}$ & $16.2 \mathrm{CD}$ & $18.5 \mathrm{C}$ & $66.5 \mathrm{~A}$ & $65.8 \mathrm{~A}$ \\
\hline AL2 SI2 O5 at $2 \%$ & $29.3 \mathrm{C}$ & $28.7 \mathrm{C}$ & $24.4 \mathrm{E}$ & $22.9 \mathrm{E}$ & 16.7CD & $20.1 \mathrm{BC}$ & $64.5 \mathrm{~A}$ & $68.3 \mathrm{~A}$ \\
\hline $\mathrm{K} 2 \mathrm{O} 3 \mathrm{Si}$ at 2500 & $31.6 \mathrm{AB}$ & $29.3 \mathrm{BC}$ & $26.6 \mathrm{CD}$ & $24.5 \mathrm{D}$ & 15.7D & $16.3 \mathrm{C}$ & $68.8 \mathrm{~A}$ & $66.3 \mathrm{~A}$ \\
\hline K2O3Si at 5000 & $33.3 \mathrm{~A}$ & $32.8 \mathrm{~A}$ & $30.2 \mathrm{~A}$ & $30.8 \mathrm{~A}$ & $9.1 \mathrm{~F}$ & $8.4 \mathrm{~F}$ & $66.0 \mathrm{~A}$ & $68.5 \mathrm{~A}$ \\
\hline Commercial * & $25.8 \mathrm{D}$ & 25.6 DE & $20.5 \mathrm{~F}$ & $19.6 \mathrm{GH}$ & $20.3 B$ & $23.3 \mathrm{~A}$ & $63.0 \mathrm{~A}$ & $67.5 \mathrm{~A}$ \\
\hline Control & $22.8 \mathrm{D}$ & $23.9 \mathrm{E}$ & $17.1 \mathrm{G}$ & $17.8 \mathrm{H}$ & $24.7 \mathrm{~A}$ & $25.5 \mathrm{~A}$ & $63.5 \mathrm{~A}$ & $68.3 \mathrm{~A}$ \\
\hline
\end{tabular}

Values followed by the same letter (s) are not significantly different at $5 \%$ level

* sprayed with water only and wrapped with paper as commercial treatment

spiration rate resulting in reduction in water loss. Another possible action of silicon is the improvement in the efficiency of osmotic adjustment of plant tissues (Romero-Aranda and Cuartero, 2006).

Silicon plays a key role in retaining the water capacity of stressed cells, which thereby can tolerate severe drought (Crusciol et al 2009) on potato. Silicon was reported to enhance rigidity, strengthening and elasticity of cell wall, also silicon promotes plant growth by correcting the levels of endogenous growth hormones, i.e., auxins, gibberellins and cytokinins under stress conditions (Hanafy et al 2008). Furthermore, potassium silicates as a foliar application provide a supplemental source of potassium. Since potassium has substantial effect on enzyme activation, protein synthesis, photosynthesis, stomatal movement and water-relation (turgor regulation and osmotic adjustment) in plants (Marschner, 1995). Increasing application of $\mathrm{K}+$ has been shown to enhance photosynthetic rate, plant growth and yield as well as drought resistance under water stress conditions (Egilla et al 2001). It was reported also that when $\mathrm{K}+$ is deficient, the stomata cannot function properly and water losses from plant may reach damaging levels (Gething, 1990 and Kamal, et al 2013). potassium silicate led to increased yield might have attributed to increased photosynthetic activity of plant, water metabolism, chlorophyllcontent, more formation of carbohydrates and more uptake of essential nutrients. (Adatia \& Besford, 1986; Nesreen et al 2011 and Lalithya et al 2013).

\section{Physical fruit properties}

\section{2.a. Fruit weight (g), Fruit height, Peel Thick-} ness and NO of Arils

Data in Table (2) declare the Effect of spraying some substance to improve fruit cracking resistance "wonderfull" pomegranates on Fruit weight (g), Fruit height $(\mathrm{cm})$, Peel Thickness $\mathrm{cm}$ and NO of Arils/tree during 2015 and 2016 seasons. It was evident from the data that, generally, all tested treatments increased Fruit weight $(\mathrm{g})$ and Fruit height as compared with the control. Differences between any of the tested treatments and the control were statistically significant.

\section{- Fruit weight (g) and Fruit height}

The greatest Fruit weight $(\mathbf{g})$ and Fruit height values 505.0 \& $480.0 \mathrm{~g}$ and $8.3 \& 8.4 \mathrm{~cm}$ during 2015 and 2016 seasons respectively resulted from sprayed fruits with K2O3Si at 5000 . 
Table 2. Effect of spraying some substance to improve fruit cracking resistance "wonderfull" pomegranates on Fruit weight $(\mathrm{g})$, Fruit height $(\mathrm{cm})$, Fruit diameter $(\mathrm{cm})$ and Peel Thickness $\mathrm{cm}$ during 2015 and 2016 seasons

\begin{tabular}{|c|c|c|c|c|c|c|c|c|}
\hline \multirow{2}{*}{ Treatments } & \multicolumn{2}{|c|}{$\begin{array}{l}\text { Fruit weight } \\
\text { (g) }\end{array}$} & \multicolumn{2}{|c|}{$\begin{array}{l}\text { Fruit height } \\
\qquad(\mathrm{cm})\end{array}$} & \multicolumn{2}{|c|}{$\begin{array}{l}\text { Fruit diameter } \\
\qquad(\mathrm{cm})\end{array}$} & \multicolumn{2}{|c|}{$\begin{array}{l}\text { Peel Thickness } \\
\text { (cm) }\end{array}$} \\
\hline & $\begin{array}{l}\text { Season } \\
2015\end{array}$ & $\begin{array}{l}\text { Season } \\
2016\end{array}$ & $\begin{array}{c}\text { Season } \\
2015\end{array}$ & $\begin{array}{c}\text { Season } \\
2016\end{array}$ & $\begin{array}{c}\text { Season } \\
2015\end{array}$ & $\begin{array}{l}\text { Season } \\
2016\end{array}$ & $\begin{array}{l}\text { Season } \\
2015\end{array}$ & $\begin{array}{c}\text { Season } \\
2016\end{array}$ \\
\hline $\mathrm{Br}$ at $5 \mathrm{PPm}$ & $480.7 \mathrm{~B}$ & $477.5 \mathrm{~A}$ & $8.1 \mathrm{AB}$ & $8.2 \mathrm{~A}$ & $14.0 \mathrm{AB}$ & $13.8 \mathrm{~A}$ & $0.66 \mathrm{~A}$ & $0.56 \mathrm{~A}$ \\
\hline $\mathrm{Br}$ at $10 \mathrm{PPm}$ & $477.5 \mathrm{CB}$ & $450.5 \mathrm{~B}$ & $7.9 \mathrm{AB}$ & $7.9 \mathrm{AB}$ & $14.0 \mathrm{AB}$ & $13.6 \mathrm{AB}$ & $0.65 \mathrm{~A}$ & $0.46 \mathrm{~A}$ \\
\hline ZnO at 1000 PPm & $390.9 \mathrm{E}$ & $398.3 \mathrm{E}$ & $7.4 \mathrm{BC}$ & $7.4 \mathrm{BC}$ & $13.2 \mathrm{BC}$ & $13.1 \mathrm{BC}$ & $0.63 \mathrm{AB}$ & $0.63 \mathrm{AB}$ \\
\hline ZnO at 2000 PPm & 455.7 D & $410.5 \mathrm{D}$ & $7.1 \mathrm{CD}$ & $7.3 \mathrm{BC}$ & $13.4 \mathrm{BC}$ & 13.6 AB & $0.63 \mathrm{~A}$ & $0.65 \mathrm{~A}$ \\
\hline AL2 SI2 O5 at $1 \%$ & $440.4 \mathrm{CD}$ & 407.3 D & $7.3 \mathrm{BC}$ & $7.5 \mathrm{~B}$ & $13.2 \mathrm{BC}$ & $13.0 \mathrm{BC}$ & $0.64 \mathrm{AB}$ & $0.65 \mathrm{~A}$ \\
\hline AL2 SI2 O5 at $2 \%$ & $455.7 \mathrm{CD}$ & $420.5 \mathrm{CD}$ & $7.5 \mathrm{~A}-\mathrm{C}$ & $7.7 \mathrm{~B}$ & 13.6 AB & $13.4 \mathrm{AB}$ & $0.64 \mathrm{~A}$ & $0.64 \mathrm{~A}$ \\
\hline K2O3Si at 2500 & $460.3 \mathrm{CB}$ & $443.0 \mathrm{BC}$ & 7.7 A-C & $7.3 \mathrm{BC}$ & $13.8 \mathrm{AB}$ & $13.4 \mathrm{AB}$ & $0.66 \mathrm{~A}$ & $0.65 \mathrm{~A}$ \\
\hline K2O3Si at 5000 & $505.0 \mathrm{~A}$ & $480.0 \mathrm{~A}$ & $8.3 \mathrm{~A}$ & $8.4 \mathrm{~A}$ & $14.2 \mathrm{~A}$ & $14.0 \mathrm{~A}$ & $0.66 \mathrm{~A}$ & $0.65 \mathrm{~A}$ \\
\hline Commercial * & $410.2 \mathrm{D}$ & $380.0 \mathrm{E}$ & $6.7 \mathrm{DE}$ & 6.6 CD & $13.2 \mathrm{BC}$ & $12.8 \mathrm{C}$ & $0.62 \mathrm{AB}$ & $0.62 \mathrm{AB}$ \\
\hline Control & $360.0 \mathrm{E}$ & $350.0 \mathrm{~F}$ & $6.1 \mathrm{E}$ & $6.1 \mathrm{D}$ & $13.0 \mathrm{C}$ & $12.6 \mathrm{C}$ & $0.59 \mathrm{~B}$ & $0.58 \mathrm{~B}$ \\
\hline
\end{tabular}

Values followed by the same letter (s) are not significantly different at $5 \%$ level

* sprayed with water only and wrapped with paper as commercial treatment

On the other hand, the lowest values of these qualities $(390.9 \& 398.3 \mathrm{~g}$ and $7.1 \& 7.3 \mathrm{~cm})$ were recorded with treated fruits with $\mathrm{ZnO}$ at $1000 \mathrm{PPm}$ in Fruit weight and $\mathrm{ZnO}$ at $2000 \mathrm{PPm}$ in Fruit height. Zinc is an essential component of some enzymes such as dehydrogenase, proteinase and peptidases. In this regard, zinc can affect electron transfer reactions such as the Krebs cycle and energy production of the plant. Zinc is also involved in other reactions such as protein construction and analysis (Bose et al 1988).

So, promote growth by increasing plasticity of the cell wall followed by the hydrolysis of starch into sugars which reduces the cell water potential, resulting in the entry of water into the cell and causing elongation (Richard, 2006).

As for the control treatment Do not spray the fruit with any substance led to reduce of weight fruit. The reduction in fruit weight was from 505.5 \& $480.0 \mathrm{~g}$ in the treated fruits of $\mathrm{K} 2 \mathrm{O} 3 \mathrm{Si}$ at 5000 to $350 \& 360.0 \mathrm{~g}$ at control treatment (about 30.7 $-28.0 \%)$

\section{- Fruit diameter and Peel Thickness}

As for Fruit diameter the fruits treated with $\mathrm{K} 2 \mathrm{O} 3 \mathrm{Si}$ at 5000 and $\mathrm{Br}$ at $5 \mathrm{PPm}$, gave significant- ly higher $(14.2 \& 14.0 \mathrm{~cm})$ in the first season and $(14.0 \& 13.8 \mathrm{~cm})$ in the second season. However, the lowest diameter value was untreated fruits which recoded $(13.0 \& 12.6 \mathrm{~cm})$ during the first \& second seasons.

Data of the two studied seasons revealed that, slight different among all treatments for Peel Thickness effect. But slight decrease were observed with the untreated fruit $(0.59 \& 0.58 \mathrm{~cm})$ or treated fruits by $\mathrm{ZnO}$ at $1000 \mathrm{PPm}(0.63 \& 0.63$ $\mathrm{cm}$ ) during both seasons under study respectively. Meanwhile slight increase were observed with treated fruit by $\mathrm{K} 2 \mathrm{O} 3 \mathrm{Si}$ at 5000 and $\mathrm{Br}$ at $5 \mathrm{PPm}$ $(0.66 \& 0.65 \mathrm{~cm})$ and $(0.66 \& 0.65 \mathrm{~cm})$ during 2015 $\& 2016$ seasons respectively.

\section{2.b. NO of Arils, arils weight, Juice weight and Pomace Weight}

Data presented in Table (3) showed the Effect of spraying some substance to improve fruit cracking resistance "Wonderful" pomegranates Fruit diameter (cm) arils' weight, juice weight and pomace weight during 2015 and 2016 seasons. 
Table 3. Effect of spraying some substance to improving fruit cracking resistance "wonderful" pomegranates on NO of Arils , Arils' Weight, Juice Weight and Pomace Weight Fruit diameter during 2015 and 2016 seasons.

\begin{tabular}{|c|c|c|c|c|c|c|c|c|}
\hline \multirow{2}{*}{ Treatments } & \multicolumn{2}{|c|}{ NO of Arils } & \multicolumn{2}{|c|}{$\begin{array}{c}\text { Arils' Weight } \\
(\mathrm{g})\end{array}$} & \multicolumn{2}{|c|}{$\begin{array}{c}\text { Juice Weight } \\
(\mathrm{g})\end{array}$} & \multicolumn{2}{|c|}{$\begin{array}{c}\text { Pomace Weight } \\
(\mathrm{g})\end{array}$} \\
\hline & $\begin{array}{l}\text { Season } \\
2015\end{array}$ & $\begin{array}{c}\text { Season } \\
2016\end{array}$ & $\begin{array}{c}\text { Season } \\
2015\end{array}$ & $\begin{array}{l}\text { Season } \\
2016\end{array}$ & $\begin{array}{l}\text { Season } \\
2015\end{array}$ & $\begin{array}{l}\text { Season } \\
2016\end{array}$ & $\begin{array}{c}\text { Season } \\
2015\end{array}$ & $\begin{array}{l}\text { Season } \\
2016\end{array}$ \\
\hline Br at s Prm & & & & & & & 41.15 & \\
\hline $\mathrm{Br}$ at $10 \mathrm{PPm}$ & $247.2 \mathrm{AB}$ & $246.5 \mathrm{~A}$ & 304.6 B & 293.7 B & $248.8 \mathrm{~B}$ & $242.3 \mathrm{~B}$ & $55.8 \mathrm{D}$ & $51.4 \mathrm{D}$ \\
\hline 10 at $1000 \mathrm{PPm}$ & 245.6 B & 243.3 AB & $259.2 \mathrm{~F}$ & 236 & 199 & & & $B$ \\
\hline ZnO at $2000 \mathrm{PPm}$ & $246.3 \mathrm{AB}$ & $245.3 \mathrm{AB}$ & 272.7 DE & $256.5 \mathrm{C}$ & $213 \mathrm{DE}$ & $201.6 \mathrm{C}$ & $59.7 \mathrm{CD}$ & $54.9 \mathrm{BC}$ \\
\hline AL2 SI2 O5 & 245.5 B & $244.2 \mathrm{AB}$ & 267 & $6 \mathrm{D}$ & $\mathrm{EF}$ & CD & $59.1 \mathrm{BC}$ & 55.7 B \\
\hline AL2 SI2 O5 at $2 \%$ & $246.7 \mathrm{AB}$ & $245.1 \mathrm{AB}$ & $282.2 \mathrm{CD}$ & $261.4 \mathrm{C}$ & $224.6 \mathrm{CD}$ & $207.02 \mathrm{C}$ & $57.6 \mathrm{CD}$ & $54.38 \mathrm{BC}$ \\
\hline K2O3Si at 2500 & $246.8 \mathrm{AB}$ & $246.2 \mathrm{AB}$ & 2 & 28 & 23 & $B$ & $57.6 \mathrm{CD}$ & $52.87 \mathrm{CD}$ \\
\hline $\mathrm{K} 2 \mathrm{O} 3 \mathrm{Si}$ at 5000 & $247.5 \mathrm{~A}$ & $248.0 \mathrm{~A}$ & $332.0 \mathrm{~A}$ & $322.08 \mathrm{~A}$ & $288.1 \mathrm{~A}$ & $276.6 \mathrm{~A}$ & $43.9 \mathrm{~F}$ & $45.84 \mathrm{E}$ \\
\hline Commercial * & $242.0 \mathrm{~B}$ & $241.2 \mathrm{~B}$ & $244.1 \mathrm{G}$ & $244.6 \mathrm{E}$ & $B$ & $265.04 \mathrm{~A}$ & $66.66 \mathrm{~A}$ & 50.2 B \\
\hline Control & $241.0 \mathrm{~B}$ & $240.3 \mathrm{~B}$ & $208.8 \mathrm{H}$ & $201,9 \mathrm{G}$ & $248.8 B$ & $242.3 \mathrm{~B}$ & $61.6 \mathrm{~B}$ & $60.7 \mathrm{~A}$ \\
\hline
\end{tabular}

Values followed by the same letter (s) are not significantly different at $5 \%$ level

* sprayed with water only and wrapped with paper as commercial treatment

\section{- NO of Arils}

Slight differences between all used treatments on arils number per fruit were noticed. However, arils number recorded the lowest values 241.0 \& 240.0 arils with treated fruits by $\mathrm{ZnO}$ at $1000 \mathrm{PPm}$ and (245.6, 243.3 arils) with the untreated fruit during both seasons under study respectively. On the other side, the highest values were achieved with treated fruit by $\mathrm{K} 2 \mathrm{O} 3 \mathrm{Si}$ at 5000 and $\mathrm{Br}$ at 5 PPm (246.8 \& $246.2 \mathrm{~cm}$ arils) in first season and (247.3 \& 247.6 arils) in second season.

\section{- Arils weight and Juice weight}

On the general side there was a positive relationship between of Juice weight and the weight of arils with the fruit weight. The treated fruits with potassium silicate at 5000 and boron at 5 PPm achieved highest significant of both qualities, which gave the highest weight to the fruit . No significant differences between the $\mathrm{ZnO}$ and $\mathrm{K} 2 \mathrm{O} 3 \mathrm{Si}$ in both concentrations, which gave intermediate values but higher than untreated or bagging treatment.

\section{- Weight of Pomace}

Regarding the weight of Pomace . It was observed that the number of arils in the fruit was almost constant and it is clear that, The weight of Pomace increases with worst treatment such as ( control, bagging(wrapping) and $\mathrm{ZnO}$ at $1000 \mathrm{ppm}$ ) and decreases with best treatments such as $(\mathrm{B}, \mathrm{Si}$ and Kaolin) in both concentration during two seasons under study.

\section{3- Chemical fruit properties}

\section{3.a. Total Acidity (\%), Total Sugars (\%) and TSS (\%)}

The results illustrated in Table (4) showed the Effect of spraying some substance to improving fruit cracking resistance "wonderfull" pomegranates on Total Acidity (\%) \& Total Sugars (\%) \& TSS (\%) during 2015 and 2016 seasons. It is worth to mention from the obtained data in Table 5 that supplying pomegranates trees with $\mathrm{K} 2 \mathrm{O} 3 \mathrm{Si}$ at 5000 and $\mathrm{Br}$ at 5 \& $10 \mathrm{PPm}$ significantly was very effective in stimulating chemical characteristics of the fruits in 
Table 4. Effect of spraying some substance to improving fruit cracking resistance "wonderfull" pomegranates on Total Acidity(\%), Total Sugars (\%) and TSS(\%)during 2015 and 2016 seasons

\begin{tabular}{|l|c|c|c|c|c|c|}
\hline \multirow{2}{*}{ Treatments } & \multicolumn{2}{|c|}{ Total Acidity } & \multicolumn{2}{c|}{ Total Sugars } & \multicolumn{2}{c|}{ TSS } \\
& \multicolumn{2}{|c}{$\%$} & \multicolumn{2}{c|}{$\%$} \\
\cline { 2 - 8 } & $\begin{array}{c}\text { Season } \\
\mathbf{2 0 1 5}\end{array}$ & $\begin{array}{c}\text { Season } \\
\mathbf{2 0 1 6}\end{array}$ & $\begin{array}{c}\text { Season } \\
\mathbf{2 0 1 5}\end{array}$ & $\begin{array}{c}\text { Season } \\
\mathbf{2 0 1 6}\end{array}$ & $\begin{array}{c}\text { Season } \\
\mathbf{2 0 1 5}\end{array}$ & $\begin{array}{c}\text { Season } \\
\mathbf{2 0 1 6}\end{array}$ \\
\hline Br at 5 PPm & $1.12 \mathrm{~B}$ & $1.15 \mathrm{C}$ & $13.6 \mathrm{~A}$ & $13.9 \mathrm{AB}$ & $16.3 \mathrm{AB}$ & $16.5 \mathrm{AB}$ \\
$\mathrm{Br}$ at 10 PPm & $1.13 \mathrm{~B}$ & $1.16 \mathrm{C}$ & $13.2 \mathrm{AB}$ & $13.7 \mathrm{AB}$ & $15.9 \mathrm{AB}$ & $16.1 \mathrm{~A}-\mathrm{C}$ \\
ZnO at 1000 PPm & $1.17 \mathrm{AB}$ & $1.34 \mathrm{~A}-\mathrm{C}$ & $12.5 \mathrm{BC}$ & $13.1 \mathrm{BC}$ & $13.7 \mathrm{CD}$ & $15.3 \mathrm{BC}$ \\
ZnO at 2000 PPm & $1.16 \mathrm{AB}$ & $1.26 \mathrm{BC}$ & $13.1 \mathrm{AB}$ & $13.1 \mathrm{BC}$ & $14.9 \mathrm{BC}$ & $15.4 \mathrm{BC}$ \\
AL2 SI2 O5 at 1 \% & $1.15 \mathrm{AB}$ & $1.28 \mathrm{~A}-\mathrm{C}$ & $13.07 \mathrm{BC}$ & $13.2 \mathrm{~B}$ & $14.8 \mathrm{BC}$ & $15.4 \mathrm{~B}$ \\
AL2 SI2 O5 at 2 \% & $1.15 \mathrm{AB}$ & $1.20 \mathrm{BC}$ & $13.0 \mathrm{~A}-\mathrm{C}$ & $13.4 \mathrm{AB}$ & $15.1 \mathrm{BC}$ & $15.5 \mathrm{BC}$ \\
K2O3Si at 2500 & $1.14 \mathrm{~B}$ & $1.17 \mathrm{C}$ & $13.4 \mathrm{AB}$ & $13.5 \mathrm{AB}$ & $15.6 \mathrm{AB}$ & $15.7 \mathrm{BC}$ \\
K2O3Si at 5000 & $1.11 \mathrm{~B}$ & $1.14 \mathrm{C}$ & $13.7 \mathrm{~A}$ & $14.2 \mathrm{~A}$ & $16.7 \mathrm{~A}$ & $17.4 \mathrm{~A}$ \\
Commercial * & $1.20 \mathrm{AB}$ & $1.38 \mathrm{AB}$ & $12.1 \mathrm{C}$ & $13.0 \mathrm{BC}$ & $13.2 \mathrm{D}$ & $15.3 \mathrm{BC}$ \\
\hline Control & $1.25 \mathrm{~A}$ & $1.47 \mathrm{~A}$ & $11.5 \mathrm{C}$ & $12.2 \mathrm{C}$ & $13.0 \mathrm{D}$ & $14.8 \mathrm{C}$ \\
\hline
\end{tabular}

Values followed by the same letter (s) are not significantly different at $5 \%$ level

* sprayed with water only and wrapped with paper as commercial treatment

terms of increasing T.S.S. \% and Total Sugars (\%). Also the same treatments significantly reduced titratable acidity. While pomegranates trees treated with bagging or untreated fruits led to reduce the values of T.S.S. \%, Total Sugars (\%) also led to increased acidity.The deterioration of the fruits resulting from cracking on pomegranate led to an increase in acidity value.

El-Sese and Mohamed (2005) reveal Si significantly increased SSC \%, but decreased the total acidity compared to the control. Carbohydrates play a vital role in the development of fruit colour, an indicator of maturity (Roper et al 1987). Further, increase in the fruit colour is due to increase in the anthocyanin content which was due to greater accumulation of carbohydrates under the influence of bioregulators. Fornes et al (1995) and Abubakar et al (2015). The positive significant effect of potassium silicate on the quality aspects of fruits in comparison with the other treatments may be attributed to the significant absorption of NPK nutrients. In addition, potassium silicate is conceder as significant supplement of $\mathrm{K}$, since potassium plays an important role in water status of plant, promoting the translocation of newly synthesized photosynthetics and mobilization of me- tabolites as well as promoting the synthesis of sugars and polysaccharides (Mengel and Kirkby, 1982). Kamal et al (2013). Silicon increased the level of sucrose and water-soluble carbohydrates. (Stamatakis et al 2003; Lynch 2008 and Lalithya et al 2013).

\section{3.b. Ascorbic Acid, Tannins and Anthocyanin}

\section{- Ascorbic acid}

Generally, it was noticed that ascorbic acid content in fruits decreased slightly with untreated fruit and bagging treatments. The results presented in Table (5), ascorbic acid content It was found that (K2O3Si at 5000)( $73.4 \mathrm{and} 78.9 \mathrm{mg})$ and $(\mathrm{Br}$ at 5 \& 10 PPm) ( 72.0 and76.8 $\mathrm{mg}) \&(70.0$ and75.1 $\mathrm{mg}$ ) which gave the highest significant values of $\mathrm{L}$ ascorbic acid compared to control in both seasons respectively. Fruits treated with ( $\mathrm{ZnO}$ at 1000 PPm) (66.2 \&70.7mg) exhibited the least value of $\mathrm{L}$-ascorbic than all treatments. 
Table 5. Effect of spraying some substance to improving fruit cracking resistance "wonder full" pomegranates on Ascorbic Acid mg/100g F.wt, Tannins \%and Anthocyanin during 2015 and 2016 seasons

\begin{tabular}{|l|c|c|c|c|c|c|}
\hline \multirow{2}{*}{\multicolumn{1}{|c|}{ Treatments }} & \multicolumn{2}{c|}{$\begin{array}{c}\text { Ascorbic Acid } \\
\text { mg/100g F.wt }\end{array}$} & \multicolumn{2}{c|}{ Tannins } & \multicolumn{2}{c|}{$\begin{array}{c}\text { Anthocyanin } \\
\%\end{array}$} \\
\cline { 2 - 7 } & $\begin{array}{c}\text { Season } \\
\mathbf{2 0 1 5}\end{array}$ & $\begin{array}{c}\text { Season } \\
\mathbf{2 0 1 6}\end{array}$ & $\begin{array}{c}\text { Season } \\
\mathbf{2 0 1 5}\end{array}$ & $\begin{array}{c}\text { Season } \\
\mathbf{2 0 1 6}\end{array}$ & $\begin{array}{c}\text { Season } \\
\mathbf{2 0 1 6}\end{array}$ & $\begin{array}{c}\text { Season } \\
\mathbf{2 0 1 5}\end{array}$ \\
\hline Br at 5 PPm & $72.0 \mathrm{~A}$ & $76.8 \mathrm{AB}$ & $2.59 \mathrm{D}$ & $2.57 \mathrm{CD}$ & $0.489 \mathrm{AB}$ & $0.553 \mathrm{AB}$ \\
Br at 10 PPm & $70.0 \mathrm{AB}$ & $75.1 \mathrm{AB}$ & $2.60 \mathrm{CD}$ & $2.59 \mathrm{CD}$ & $0.481 \mathrm{AB}$ & $0.513 \mathrm{AB}$ \\
ZnO at 1000 PPm & $66.2 \mathrm{CD}$ & $70.7 \mathrm{C}$ & $2.70 \mathrm{BC}$ & $2.81 \mathrm{~A}$ & $0.396 \mathrm{D}$ & $0.488 \mathrm{BC}$ \\
ZnO at 2000 PPm & $69.8 \mathrm{BC}$ & $72.9 \mathrm{~B}$ & $2.69 \mathrm{BC}$ & $2.73 \mathrm{BD}$ & $0.422 \mathrm{CD}$ & $0.486 \mathrm{BC}$ \\
AL2 S12 05 at 1\% & $67.3 \mathrm{~B}-\mathrm{D}$ & $71.2 \mathrm{C}$ & $2.75 \mathrm{AB}$ & $2.78 \mathrm{~A}$ & $0.436 \mathrm{BC}$ & $0.452 \mathrm{CD}$ \\
AL2 SI2 05 at 2\% & $71.4 \mathrm{AB}$ & $73.3 \mathrm{BC}$ & $2.66 \mathrm{CD}$ & $2.64 \mathrm{AB}$ & $0.411 \mathrm{CD}$ & $0.445 \mathrm{CD}$ \\
K2O3Si at 2500 & $70.3 \mathrm{AB}$ & $74.0 \mathrm{~A}-\mathrm{C}$ & $2.61 \mathrm{CD}$ & $2.56 \mathrm{D}$ & $0.452 \mathrm{BC}$ & $0.495 \mathrm{BC}$ \\
K203Si at 5000 & $73.4 \mathrm{~A}$ & $78.9 \mathrm{~A}$ & $2.65 \mathrm{D}$ & $2.45 \mathrm{D}$ & $0.577 \mathrm{~A}$ & $0.511 \mathrm{~A}$ \\
Commercial * & $66.7 \mathrm{D}$ & $66.7 \mathrm{D}$ & $2.78 \mathrm{AB}$ & $2.80 \mathrm{~A}$ & $0.394 \mathrm{D}$ & $0.412 \mathrm{D}$ \\
\hline Control & $63.1 \mathrm{D}$ & $66.3 \mathrm{D}$ & $2.84 \mathrm{~A}$ & $2.84 \mathrm{~A}$ & $0.372 \mathrm{D}$ & $0.407 \mathrm{D}$ \\
\hline
\end{tabular}

Values followed by the same letter (s) are not significantly different at $5 \%$ level

* sprayed with water only and wrapped with paper as commercial treatment

\section{- Total tannins}

An evident, significant effects in both seasons on total tannins were detected in all treatments, total tannins of fruit juice wonderful ranged from (2.59 to $2.84 \%$ \%). K2O3Si at $2500 \& 5000$ ppm had recorded the best treatment of total tannins. On the other hand, worst treatment was recorded by (AL2 $\mathrm{SI} 2 \mathrm{O} 5$ at $1 \%$ and untreated fruits without significant different between them $2.75 \& 2.84 \%$ in first season and $2.78 \& 2.84 \%$ in second season. Ascorbic acid is an important nutrient quality parameter and is very sensitive to degradation due to its oxidation compared to other nutrients during food processing (Veltman et al $\mathbf{2 0 0 0}$ and Samah Nasr et al 2013).

\section{- Anthocyanins pigment content (\%)}

By reference to Table (1) (percentage of cracking) it was observed that the treatments that gave the lowest value gave the highest percentage of anthocyanin and vice versa. Untreated fruit recorded the lest values of pigment anthocyanins which achieve $(0.372 \& 0.407 \%)$, gave the highest cracking values $(24.7 \& 25.5 \%)$ in both seasons respectively. In the contrast $\mathrm{K} 2 \mathrm{O} 3 \mathrm{Si}$ at 5000 and $\mathrm{Br}$ at 5 \& $10 \mathrm{PPm}$ gave the highest values of pigment anthocyanins content. (0. 577, 0.489 and 0.481 in 2015 season) and $0.511,0.553$ and 0.513 in 2016 season with slight different among them, these treatments have been recorded least percentage of cracking. (9.1, 11.3 and $12.6 \%$ in 2015 season) and $0.8 .4,12.4$ and $14.4 \%$ ) in 2016 season respectively.

Silicate gave a higher significant value of anthocyanin than untreated fruits. and prevent the sunburn damage completely and enhanced anthocyanin contents in skin and seed. (Kulkarni \& Aradhya, 2005 and Samra et al 2013).

\section{ACKNOWLEDGMENT}

I would like to extend my heartfelt thanks to my second mother and her heart-giving, Dr Samah Nasr Researcher at the Higher Institute for Cooperation on Agriculture - Shubra Al Khaimah Cairo, for her constant helps, rich constructive information and great efforts. She supported me in this research and wished her all the happiness and all her love and appreciation for this work. 


\section{REFERENCES}

A.O.A.C. 2000, Official Methods of analysis 15thEdition. Association of Official Anal Chem. Vol. 2: 918 p. (942015), Washington, D.C., USA

Abd El-Fatah DM, Mohamed, S.A. and Ismail, O.M. 2008 Effect of biostimulants, ethrel, boron and potassium nutrient on fruit quality of "Costata" persimmon. Aust. J. Basic Appl. Sci., 2(4),1432-1437.

Abd El-Rhman, I.E. 2010. Physiological studies on cracking phenomena of Pomegranates. J. Appl.

Abubakar, A.R., Ashraf, N. and Ashraf, M. 2013 Effect of plant biostimulants on fruit cracking and quality attributes of pomegranate cv. Kandhari kabuli . Academic J.. 8(44), 2171- 2175.

Adatia, M.H. and Besford, R.T. 1986. The effects of silicon on cucumber plants grown in recirculatingnutrient solution. Ann. Bot. London, 58, 343-518.

Al-Maiman, S.A. and Ahmad, D. 2002. Change in physical and chemical properties during pomegranate (Punica granatum) fruit maturation. In: Food Chem., 76, 437-441

Aseri, G.K., Jain, N., Panwar, J., Rao, A.V. and Meghwal, P.R. 2008. Biofertilizers improve plant growth, fruit yield, nutrition, metabolism and rhizosphere enzyme activities of Pomegrante (Punica granatum L.) in Indian Thar Desert. Sci. Hort., 117, 130-136.

Bahadur, L., Malhi, C.S. and Singh, Z. 1998. Effect of foliar and soil application of zinc sulphate on zinc uptake, tree size. Yield, and fruit quality of mango. J. of Plant Nutrition, 21(3), 589- 608.

Baiea, M.H.M., El-Sharony, T.F., Eman, A. Abd El- Moneim, A. 2015. Effect of different forms of potassium on growth, yield and fruit quality of mango cv. Hindi International J. of Chem. Tech Research. 8(4), 1582-1587.

Balakrishnan, K., Vekatesan, K., Sambandamurthis, S. 1996. Effect of foliar application of $\mathrm{Zn}, \mathrm{Fe}, \mathrm{Mn}$ and $\mathrm{B}$ on yieldquantity of pomegranate, cv. Ganesh. Orissa J. Hort., 24(1 -2), 33 35.

Baldi, E., Toselli, M., Deudellar, D., Taglivini, M. and Maringoni, B. 2004. Foliar feeding of stone fruit trees. Informatore-Agrorio, 60(21), 43-46.

Bambal, S.B., Wavhal, K.N. and Nasalkar, S.D. 1991. Effect of foliar application of micronutrients on fruit quality and yield of pomegranate (Punica granatum L. cv. Ganesh). Maharashtra J. of Hort., 5(2), 32-36.
Banik, B.C., Sen, S.K. and Bose, T.K. 1997 .Effect of zinc, iron and boron in combination with urea on growth ,flowering ,fruiting and fruit quality of mango cv. Fazli. Environment and Ecology. 15(1), 122-125.

Bertling, I., Tesfay, S.Z., Bower, J.P. and Kaluwa, K. 2009. Effect of post-harvest application of silicon on 'Hass' avocado fruit. South African Avocado Crowers' Association Yearbook 32, 53-56.

Bose, T.K., Mitra, S.K. and Sadju, M.K. 1988. Citrus. In: The mineral nutrition of fruit crop. Ed. Naya, Prokash, Calcutta. India, pp, 70- 90.

Chérif, M., Asselin, A. and Bélanger, R.R. 1994. Defence responses induced by soluble silicon in cucumber roots infected by Pythium spp. Phytopathol. 84(3), 236-242.

Creamer, Sanogo, R.S. and El-Sebai O.A. 2005. Kaolin-basedfoliarreflectant affects physiology and incidence of beetcurly top virus but not yield of Chile pepper. Hort. Sci., 40(3), 574-576.

Crusciol, C.A.C., Pulz, A.L., Lemos, L.B., Soratto, R.P. and Lima, G.P.P. 2009. Effects of silicon and drought stress on tuber yield and leaf biochemical characteristics in potato. Crop Physiology and Metabolism, 49, 949954

Efimova, G.V. and Dokynchan, S.A. 1986. Anatomo-morphological construction of epidermal tissue of rice leaves and increasing of its protection function under silicon effect. Agric. Biol., 3, 57-61.

Egilla, J.N., Davies, F.T. and Drew, M.C. 2001. Effect of potassium on drought resistance of Hibiscus rosa-sinensis cv. Leprechaun: Plant growth, leaf macro and micronutrient content and root longevity. Plantand Soil, 229(2), 213224.

EL-Sese, A.M. and Mohamed, A.K.A. 2005. Effect of flower thinning on yield, fruit splitting and quality of Manfalouty pomegranate cultivar. Agric. Sci., Mansoura Univ., 30(1), 501-511.

Epstein, E. 1999. Silicon. Annu Rev Plant Physiol, Plant Mol. Biol., 50, 641-664.

Ergun, M. 2012. Postharvest quality of Galaxy apple fruit in response to kaolin-based particle film application. J. Agric. Tech., 14, 599-607.

Fornes, F., Sanchez, P.M. and Guardiola, J.L. 1995. Effect of a seaweed extract on citrus fruit maturation. Acta Hort., 379, 75-82.

Gething, P.A. 1990. Potassium and water relationships. In: Potash facts. IPI. Bern.

Glenn, D.M. and Puterka G.J. 2007. The use of plastic films and sprayable reflective particle 
films to increase light penetration in apple canopies and improve apple color and weight. Hort. Sci., 42(1), 91-96.

Glenn, D.M., Puterka, G.J., Vvonderzwet, T.E., Byer, R. and Feldhake, C. 1999. Hydrophobic particle films: a new paradigm for suppression of anthropoid pests and plant diseases. J. Econ. Entomol. 92, 759-771.

Gong, H., Zhu, X., Chen, K., Wang, S. and Zhang, C. 2005. Silicon alleviated oxidative damage of wheat plants in pots under drought. Plant Sci. 169, 313-321.

Hamouda, H.A., Elham, Z.A. and Nagwa, G.Z. 2015. Nutritional Status and Improving Fruit Quality by Potassium Magnesium and Manganese Foliar Application in Pomegranate Shrubs. International J. of Chem. Tech Research, 8(6), 858-867.

Hanafy, Ahmad, A.H., Horb, E.M., Higazy, M.A. and Morgan, Sh.H. 2008. Effect of silicon and boron foliar applications on wheat plants grown under saline conditions. Sci. Alert, 10, 1-32.

Hasani, M., Zamani, Z., Savaghebi, G. and Fatahi, R. 2012. Effects of zinc and manganese as foliar spray on pomegranate yield, fruit quality and leaf minerals. J. of Soil Sci. and Plant Nutrition, 12(3), 471-480

Hassan, R.E., Kashani, S.F. and Ebrahimi, L. 2013. Combination of silicon and hot water to control of postharvest blue mould caused by penicillium expansum in apple. International $\mathbf{J}$. of Agric. Research and Review, 3(1), 72-79.

Hegazi, A., Samra, N.R., El-Baz, E.E.T., Bahan. M.Kh. and Gawish, M.S. 2014. Improving fruit quality of manfaloty and wonderfull pomegranates by using bagging and some spray treatments with gibberellic acid, calcium chloride and kaolin. J. Plant Production, Mansoura Univ., 5(5), 779-792.

Jing, L., Yang, Q., Xiao-gang, L., Sheng, B., Wang, Z. and Chang, Y. 2009. Effect of microenvironment of bagging on appearance quality of 'Cuiguan' pears. J. Northwest A \& F Univ., Natural Sci., 37(10) 133-139.

Kahn, B.A. and Damicone J.P. 2008. Kaolin particle film product applications before harvest begins may not improve marketable yields of fresh tomatoes. Hort. Technology, 18(1), 144-147.

Kamal, A.M. 2013. Influence of irrigation levels, anti transpirants and potassium silicate on growth, fruit yieldand quality of sweet pepper plants(Capsicum annuumL.) grown under drip irrigation. J. Plant Production, Mansoura Univ., 4(11), 1581 -1597.
Khayyat, M., Tafazoli, E., Eshghi, S. and Rajaee, S. 2007. Effect of nitrogen, boron, potassium and zinc sprays onyield and fruit quality of date palm. American-Eurasian J. Agric. Environ. Sci., 2, 289-296.

Khorsandi, F., Alaei Yazdi, F. and Vazifehshenas M.R. 2009. Foliar zinc fertilization improves marketable fruit yield and quality attributes of pomegranate. Int. J. Agric. Biol., 11(6), 766770.

Kulkarni, A.P. and Aradhya, S.M. 2005. Chemical changes and antioxidant activity in pomegranate arils during fruit development. Food Chem., 93, 319-324.

Kumar, R., Bakshi, P. and Srivastava, J.N. 2010. Fruit Cracking: A Challenging Problem of Fruit Industry. Krishi Sandesh.

Lalithya, K.A., Bhagya, H.P., Bharathi, K. and Kulapati, H. 2014. Response of soil and foliar application of silicon and micro nutrients on leaf nutrient status of sapota. An International Quarterly J. of Life Sci., 9(1), 159-162.

Lynch, M. 2008. Silicates in cotemporary Australian farming: A 20- year Review. Silicon in Agric. Conference. South Africa.

Mditshwa, A., Bower, J.P., Bertling, I., Mathaba N. and Samson Z.T. 2013. The potential of postharvest silicon dips to regulate phenolics in citrus peel as a method to mitigate chilling injury in lemons. African J. of Biotechnology, 12(13), 1482-1489,

Melgarejo, P. and Martinez, M. 1992. ElGranado. Ed. Mundi-prensa, $163 \mathrm{p}$.

Mengel, K. and Kirkby, E.A. 1982. Textbook of principles of plant nutrition. 655. p. International Potash Institute, Bern, Switzerland.

Menzies, J.G., Ehret, D.L., Glass, A.D., Helmer M., Koch, T. and Seywerd, F. 1991. The effects of soluble silicon on the parasitic fitness of Sphaerotheca fuliginia on Cucumis sativus. Phytopathology 81, 84-88.

Neilsen, G.H., Neilsen, D., Hogue, E.J. and Herbert, L.C. 2004. Zinc and boron nutrition management in fertigated high density apple orchards. Can. J. Plant Sci., 84, 823-828.

Nesreen, H., Abou-Baker, A.M. and Abbas, M.M. 2011. Use of silicate and different cultivation practices in alleviating salt stress effect on bean plants. Aust. J. Basic \& Appl. Sci., 5, 769-815.

Nijjar, G.S. 1985. Nutrition of fruit trees. Mrs Usha Raj Kumar, Kalyani, New Delhi, India, pp. 306308. 
Palitha, W.J., Magdalena, M. and Rogers, J. 2010. The effect of maturity, sunburn and application of sunscreen on the internal and external qualities of pomegranate fruit grown in Australia. Scientia Hort. 124, 57-61.

Palou, L., Carlos, H., Aguilar, G. and David, G. 2007. Combination of postharvest antifungal chemical treatments and controlled atmosphere storage tocontrol gray mold and improve storability of 'Wonderful' pomegranates. Postharvest Biology and Technol., 43, 133-142.

Rajput, R.S., Shigh, A.R. and Pande, N.C. 1991. Role of potas and zinc on the biochemical parameters of Kagzi lime. J. Hort. Sci., 18, 41 50.

Ranjit, K., Kumar, P. and Singh, U.P. 2008. Effect of foliar application of nitrogen, zinc and boron on flowering and fruiting of mango cv Amrapali. Environ. Ecol. 26, 1965-1967.

Rashmi, P., Sing, R. and Pantnagar, C.P. 2007. Effect of preharvest foliar spray of micronutrients on chemical properties of mango fruit cv. Langra. J. Res., 5, 56-61.

Richard, M. 2006. How to grow big peaches. Department of Horticulture, Virginia Tech. Blacksburg, VA 24061. Internet, www. Rce.rutgers.edu. 8 ,

Romero-Aranda, M.R., Jurado, O. and Cuartero, J. 2006. Silicon alleviates the deleterious salt effects on tomato plant growth by improving plant water status. J. Plant Physiol., 163, 847-855.

Roper, T.R., Loescher, W.H., Keller, J. and Rom C.R. 1987. Sources of photosynthate for fruit growth in 'Bing' sweet cherry. J. Am. Soc. Hort. Sci., 112, 808-812.

Saleh M.M. and Abd El-Monem. E.A. 2003. Improving productivity of" fagri kalan" mango trees grown under sandy soil conditions using potassium, boron and sucrose as foliar spray. Ann. Agric. Sci., 48, 747-756.

Samah Nasr, Korkar, I.H.M. and Abdel Hamid, A. 2013. Evaluate the use permeable silicon with MAP to extend the quality of pioneer plums during the two different storage temperatures. World J. of Agric. Sci., 9(6), 454-465.
Samra, B.N. and Shalan, A.M. 2013. Studies on thinning, bagging and aluminum silicate spraying on yield and quality of Wonderful pomegranate. J. Plant Production, Mansoura Univ., 2, 219-227.

Sarkhosh A., Zamani, Z., Fatahi, R. and Ebadi, A. 2006. RAPD markers reveal polymorphism among some Iranian pomegranate(Punica granatum L.) genotypes, Sci. Hort. 111, 24-29.

Schupp, J.R., Fallahi, E. and Chun, I.J. 2002. Effect of particle film on fruit sunburn, maturity and quality of "Fuji" and "Honeycrisp" apples. Hort. Technology. 12, 87-90.

Sekse, L., Bjerke, K.L. and Vangdal, E. 2005. Fruit cracking in sweet cherries - An integrated approach. Acta Hortic. 667, 471-474.

Singh, G. and Maurya, A.N. 2004. Effect of, micronutrients on bearing of mango cv. Mallika. Progressive Agric., 4, 47-50.

Snedecor, C.W. and Cochran, W.G. 1982. Statistical Methods. $7 \mathrm{Ed}$. The lowa State Univ. Press. Ames.th lowa, USA.

Srihari, D. and Rao, M.M. 1998. Effect of spraying nutrients and chemicals on vegetative growth and flowering in off phase Alphonso mango trees. Karnataka J. Agric. Sci., 11, 257-259.

Stamatakis, A., Papadantonakis, N., Ydakis, L., Simantiris, N., Kefalasand, P., Savvas, D. 2003. Effects of silicon and salinity on fruit yield and quality of tomato grown hydroponically. Acta Hort. 609, 141-471.

Swain, J. and Hillis, W.E. 1959. The Phenolic Constitutents of Prunus domestica. I. The Quantitative Analysis of Phenolic Constituents. J. of the Sci. of Food and Agric., 10, 63-68.

Swietlik, D. 1999. Zinc nutrition in horticultural crops. Hort. Reviews 23, 109-180.

Taiz, L. and Zeiger, E. 2006. Plant Physiology. (2nded.), Sinauer Associates Publishers, Sunderland,. pp. 617-634.

Veltman, R.H., Kho, R.M.A., Van-Schaik, C.R.M. Sanders, G., Oosterhaven, J. 2000. Ascorbic acid and tissue browning in pears under controlled atmosphere conditions, Postharvest Biology and Technology Amsterdam, 19, 129137.

Wahdan, M.T., Habib, S.E. Bassal M.A. and Qaoud, E.M. 2011. Effect of some chemicals on growth, fruiting, yield and fruit quality of "Succary Abiad" mango cv. J. of American Sci., 7(2), 651-658. 